\title{
Relationship intention amongst clothing retail customers: An exploratory study
}

\author{
Authors: \\ Stefanie W. Kuhn ${ }^{1}$ \\ Pierre G. Mostert ${ }^{2}$ \\ Affiliations: \\ ${ }^{1}$ Research Unit for Economic \\ and Management Sciences, \\ North-West University, \\ Potchefstroom Campus, \\ South Africa \\ ${ }^{2}$ Department of Marketing \\ Management, University of \\ Pretoria, South Africa \\ Correspondence to: \\ Stefanie Kuhn

\section{Email:} \\ stefanie.kuhn@nwu.ac.za

\section{Postal address:} \\ Private Bag X6001 \\ Potchefstroom 2520, \\ South Africa

\section{Dates:} \\ Received: 11 Dec. 2014 \\ Accepted: 23 June 2015 \\ Published: 31 Aug. 2015 \\ How to cite this article: \\ Kuhn, S.W. \& Mostert, P.G., \\ 2015, 'Relationship intention \\ amongst clothing retail \\ customers: An exploratory \\ study', Acta Commercii \\ 15(1), Art. \#302, 12 pages. \\ http://dx.doi.org/10.4102/ \\ ac.v15i1.302

\section{Copyright:} \\ (C) 2015. The Authors. \\ Licensee: AOSIS \\ OpenJournals. This work is \\ licensed under the Creative \\ Commons Attribution \\ License.
}

Read online:

Scan this $Q R$ code with your smart phone or mobile device to read online.
Orientation: Increasing competition has resulted in clothing retailers placing more emphasis on expensive relationship marketing tactics to retain customers. The retailers often use customers' loyalty programme membership and the duration of their support to identify and target them in relationship-building efforts.

Research purpose: This study determines the viability of relationship intention by measuring and categorising clothing customers according to their relationship intentions. The study also explores the duration of customer support for a clothing retailer, membership of their loyalty programme and the relationship thereof with customers' relationship intentions towards that retailer.

Motivation for the study: Relationship building efforts would be better directed at customers with relationship intentions.

Research design, approach and method: Quantitative in nature, this study followed a descriptive research design and used an interviewer-administered survey to collect data from 511 clothing retail customers residing in the greater Pretoria metropolitan area.

Main findings: Clothing retailers can effectively determine and categorise customers according to their relationship intentions. The duration customers have supported a clothing retailer and its loyalty programme has no relationship with their relationship intentions.

Practical/Managerial implications: Clothing retailers should focus their relationship building on customers with relationship intentions, as they are more likely to respond favourably. They are more likely to be retained by the clothing retailer and provide a return on investment.

Contribution/value-add: This study gives clothing retailers a reliable and valid measuring instrument that can be used to identify customers with relationship intentions, rather than relying on the duration of the customers' support and their loyalty programme membership.

\section{Introduction}

Whilst the benefits of relationship marketing, such as increased customer loyalty, referrals and spending, are well documented in literature (Agariya \& Singh 2011:228; Mark et al. 2013:233). However, the applicability of these benefits to consumer markets like the clothing retail sector is questionable (O'Malley \& Tynan 2000:797). Some marketing scholars argue that the size of the consumer markets and the customers' need for variety tend to limit the number of meaningful interactions retailers can have with their customers. This is a challenge to the development of successful customer relationships (De Wulf et al. 2003). Nevertheless, in the face of aggressive pricing and the absence of switching barriers, more clothing retailers are using relationship marketing tactics to improve customer retention and profitability (De Cannière, De Pelsmacker \& Geuens 2010:87; MarketLine 2014:13). Consequently, it has become increasingly important for clothing retailers to understand how to establish and maintain successful customer relationships (Leahy 2011:652).

When deciding on which customers to build long-term relationships (Meyer-Waarden 2008:87), clothing retailers consider both loyalty programme membership and for how long customers have been supporting them as an indication of relationship formation (Bolton, Kannan \& Bramlett 2000:95). The idea of using the duration of customers' support as an indicator of their relationship intentions stems from the belief that the impact of relationship marketing tactics on relationship investment increases over time (De Wulf, Odekerken-Schröder \& Iacobucci 2001:47; Ward \& Dagger 2007:282) and that customer lifetime value and profitability increases commensurate with the duration of their support (Liang \& Wang 2006:142).

Despite organisational efforts to build relationships with customers, it is the latter who dictate whether relationships are going to develop in the business-customer context (Bove \& Mitzifiris 2007:508; Fernandes \& Proença 2013:42). Clothing retailers should therefore determine their 
customers' conscious tendency to engage in relationships with organisations (relationship intention) (Kumar, Bohling \& Ladda 2003:670; Odekerken-Schröder, De Wulf \& Schumacher 2003:180) to ensure that the customers who are most likely to respond to relationship-building efforts are targeted (Raciti, Ward \& Dagger 2013:615).

Although clothing retailers benefit from categorising customers according to their relationship intentions, this has not been explored in the context of retail. Furthermore, the literature search revealed no empirical evidence as to whether customers' loyalty programme membership and the duration of their support could indicate their relationship intentions in this context. This article argues that customers' relationship intentions should be used to categorise and target customers for the purpose of relationship marketing, because their relationship intentions determine whether clothing retailers' relational efforts will be favourably received and acted upon (De Wulf et al. 2001:34; Fernandes \& Proença 2013:42). The purpose of this study is, firstly, to determine the viability of considering relationship intention in the clothing retail context by measuring, and then categorising, clothing retail customers according to their relationship intentions. The study furthermore explores the relationship between clothing retailer customers' relationship intentions and the length of time they have supported a clothing retailer, as well as their membership to the clothing retailer's loyalty programme.

\section{Literature review}

\section{Relationship marketing in the retail context}

Relationship marketing focuses on retaining existing customers by creating and preserving mutually beneficial, long-term relationships (Christopher, Payne \& Ballantyne 2008). The significance of focusing on relationship marketing tactics stems from the notion that building strong customer relationships leads to increased satisfaction, loyalty and customer referrals (Adjei, Griffith \& Noble 2009:493; Wong \& Sohal 2006:244). Retailers fostering long-term relationships with customers also benefit financially from the lower cost of acquiring customers and increasing their purchases (Ashley et al. 2011:749; Mark et al. 2013:233). Considering these benefits, it is not surprising that more retailers are pursuing long-term relationships with customers to gain a strategic and competitive advantage (De Cannière et al. 2010:87).

Relationships between retailers and customers come about when retailers respond promptly to, and satisfy, their customers' needs (Adjei et al. 2009:494; Johnson \& Ross 2014:207). This, in turn, increases the customers' willingness to exchange information that allows the retailers to gain a deeper understanding of those needs and how to satisfy them better than their competitors can do (Ashley et al. 2011:749). Sheth and Parvatiyar argue that customers fundamentally engage in relationships with organisations for the purposes of choice reduction, which results in more efficient information processing and decision making. Particularly in the retail context, choice reduction is demonstrated in customers' inclination to patronise the same retailer over a period of time (Sheth \& Parvatiyar 1995:256).

Notwithstanding the fact that relationship marketing offers mutual benefits for retailers and their customers, marketing academics have criticised the application of a relationship marketing approach in consumer markets on account of the size of the market and the limited customer interactions (Leahy 2011:651). Despite this valid criticism, retailers continue to invest in relationship building as a customer retention strategy (Bojei et al. 2013:171; Grewal \& Levy 2007:449). It thus becomes essential to understand the dynamics of relationship marketing in consumer markets, including how relationships between retailers and customers develop (Adjei \& Clark 2010:73; Mark et al. 2013:233). As customers' desires to enter into a relationship ultimately affect the effectiveness of retailers' relationship marketing efforts (Palmatier et al. 2007:210), customers' intentions to engage in relationships with retailers should be scrutinised (Raciti et al. 2013:616).

\section{Relationship intention}

Some customers may be indifferent to retailers' relationshipbuilding efforts (Adjei \& Clark 2010:73) by focusing more on transactional exchanges (Dalziel, Harris \& Laing 2011:399). Consequently, retailers' efforts would be better directed at customers who are likely to respond to these efforts (Palmatier et al. 2007:210; Parish \& Holloway 2010:63), that is, those who have relationship intentions. Relationship intention represents customers' conscious and planned desire to engage in a relationship with an organisation whilst buying products or services attributed to the organisation itself, a brand or a channel (Kumar et al. 2003:667; Raciti et al. 2013:615). Kumar et al. (2003:667), who first introduced the relationship intention construct, suggest that customers' relationship intentions consist of five sub-constructs: involvement, feedback, expectations, forgiveness and fear of loss of relationship.

\section{Involvement}

Baker, Cronin and Hopkins (2009:116) explain that involvement is a function of the personal relevance that an object (for example, a product, a service or a relationship with an organisation) has for customers, along with their willingness to engage in the activities associated with that object. Furthermore, involvement plays a role in customers' decision making, as involved customers demonstrate greater motivation to collect and process marketing information (Dagger \& David 2012:450; Kinard \& Capella 2006:365). Information processing and customer decision making influences customers' interest in relationships with organisations (Varki \& Wong 2003:89). Involvement should therefore be viewed as fundamental to the understanding of customer-organisational relationships, as involvement influences customers' receptivity to organisations' relationship marketing efforts (Kinard \& Capella 2006:365; O'Cass 2000:551). 
Building on the premise that involvement influences customer decision making and that involved customers engage willingly in activities associated with objects of personal relevance (Dagger \& David 2012:450), it can be deduced that customers' involvement indicates their relationship intentions. Kumar et al. (2003:670) concur, arguing that involved customers engage in relationship activities with organisations without being forced to do so. Customers with relationship intentions not only display greater involvement with a retailer, but also value regular feedback to, and from, the retailer (Ashley et al. 2011:754; Baker et al. 2009:117).

\section{Feedback}

Customer feedback, whether positive or negative, is a valuable source of managerial information (Voss et al. 2004:212), as it is an opportunity for organisations to learn from customer interactions (Caemmerer \& Wilson 2010:289), thereby highlighting organisational strengths and generating new ideas for service improvements (Wirtz, Tambyah \& Mattila 2010:363). Feedback identifies problem areas and is an opportunity for an organisation to rectify problems that may occur during service delivery, thus preventing dissatisfied customers from defecting to competitors and spreading negative word-of-mouth remarks to others. Consequently, customer feedback is appreciated as a customer relationship driver (Lacey 2012:137).

Previous research suggests that customers who have strong relationships with organisations are more at ease in providing feedback (Rothenberger, Grewal \& Iyer 2008:359), and are motivated to communicate with organisations about correcting problems, as opposed to terminating a relationship when service transgressions occur (Lacey 2012:138). Subsequently, customers' willingness to give an organisation feedback is indicative of strong customer-organisational relationships (Blodgett, Wakefield \& Barnes 1995:31), and also of their relationship intentions towards that organisation (Kumar et al. 2003:670). Kumar et al. (2003:670) add that customers with relationship intentions are motivated by altruism to give the organisation both positive and negative feedback on their expectations.

\section{Expectations}

Expectations denote customers' beliefs about a product, service or organisation, derived from previous experiences (Wilson et al. 2012:51). These beliefs, in turn, become reference points or standards against which to judge performances (Zeithaml, Berry \& Parasuraman 1993:1). Consequently, expectations significantly influence customer satisfaction (Oliver 1980:460), and, ultimately, their behavioural intentions (Choy, Lam \& Lee 2012:14).

Customer expectations differ, depending on the type of relationship they have with an organisation (Mason \& Simmons 2012:231). For example, customers in established relationships with organisations often have higher expectations of the organisations. To sustain customer-organisational relationships requires considerable investment of irrecoverable resources, including time and effort (De Wulf et al. 2001:34; Liang \& Wang 2006:120-121). Kumar et al. (2003:670), therefore advocate that customers who expect more from organisations are concerned with the enhancement of organisational products and services and are thus more intent on building relationships.

\section{Forgiveness}

Although the strongest customer-organisation relationships are susceptible to disruption and problems when customer expectations are not met (Tsarenko \& Tojib 2011:383), research has shown that strong customer relationships give organisations some protection after a service transgression has occurred (Priluck 2003:37; Yu \& Xie 2011:1). Kim, Ok and Canter (2012:60-61) and Singh and Sirdeshmukh (2000:150) explain that customers in strong organisational relationships display greater tolerance of service failures, and are therefore more likely to forgive organisations for their poor product or service experiences. Such customers are also more likely to forgive service transgressions, as they expect to maintain their relationships with the organisation in the future (Priluck 2003:37; Yu \& Xie 2011:1). Kumar et al. (2003:670) accordingly suggest that customers' willingness to forgive an organisation when their expectations are not met, or when transgressions occur, reveals their relationship intentions towards the organisations.

\section{Fear of relationship loss}

Customers' wishes to maintain organisational relationships are embedded in the relational benefits arising from such relationships, including confidence and social and special treatment benefits (Bojei et al. 2013:171; HenningThurau, Gwinner \& Gremler 2002:234). Dagger, David and $\mathrm{Ng}$ (2011:273) posit that customers in organisational relationships experience less anxiety, as they know what to expect from an organisation (confidence benefits).They receive personal recognition, familiarity and friendship from the organisation's employees (social benefits), as well as discounted prices and customised product or service offerings (special treatment benefits).

These relational benefits facilitate the formation of relational bonds, when customers interact satisfactorily with organisations over consecutive time periods (Homburg, Giering \& Menon 2003:44; Liang \& Wang 2007:339). Relational bonds include financial items (price attractions and discounts to stimulate customer consumption), social aspects (a sense of affiliation through the provision of support, advice and empathy during interactions), and structural bonds (rules, policies, procedures, infrastructure or agreements) that give formal structures for relationships and interactions) (Liang \& Wang 2007:339-341; Wilson et al. 2012:154). Relational bonds also increase customers' perceptions of switching cost, that is, the cost of lost resources invested when they transfer to another organisation (Jones et al. 2007:337). 
As the establishment of customer-organisational relationships requires the investment of customer effort and time (Vázquez-Casielles et al. 2009:2293), any perceived loss of relational benefits, termination of relational bonds, and possible switching costs give rise to customer concern about the consequences that may come about should their relationship with an organisation end (Jones et al. 2007:337; Kumar et al. 2003:670). Therefore, customers who fear losing their relationship with an organisation demonstrate relationship intentions (Kumar et al. 2003:670).

\section{Loyalty programmes and South African clothing retailers}

A loyalty programme is an integrated system of marketing activities aimed at increasing customer spending, loyalty, and ultimately retention by rewarding customers for repeated patronage (Meyer-Waarden 2008:89; Vesel \& Zabkar 2010:1339). If they want to join a retailer's loyalty programme, customers usually have to apply to become a member, after which they are issued with a loyalty card to validate their membership so that they can take advantage of the rewards offered (Leenheer \& Bijmolt 2008:429). Rewards, such as price discounts and gifts, are obtained either immediately when customers present their loyalty card, or when their points, accumulated over a period of time, are redeemed (Liu 2007:20).

It is believed that loyalty programmes facilitate customer relationship development in a number of ways. Firstly, loyalty programmes allow retailers to obtain information about their customers' product and retail mix preferences (Mauri 2003:13), which enables the retailers to better satisfy customer needs, a necessary condition for relationship formation (Adjei et al. 2009:494). Secondly, as loyalty programmes require the investment of considerable irretrievable resources, it signals the retailers' intention to sustain the customer relationships (Leenheer \& Bijmolt 2008:429; Liu 2007:19). Lastly, loyalty programmes focus on encouraging customer loyalty by rewarding customers for their continued patronage (De Wulf \& Odekerken-Schröder 2003:97; Leenheer \& Bijmolt 2008:429; Liu 2007:19). It is thus understandable that clothing retailers increasingly use loyalty programmes as one of their relationship marketing strategies for establishing and strengthening customer relationships and stimulating customer loyalty (Huang 2015:1318; Leenheer \& Bijmolt 2008:429).

South African examples of clothing retailers using loyalty programmes include the WRewards card from Woolworths, the TFG Rewards \& More card from Foschini, the Thank U Rewards card from Edgars and the PEPclub card from Pep Stores (Pep Stores 2014; Thank U Rewards 2014; The Foschini Group 2014; Woolworths 2014). The WRewards card focuses on dividing customers into tiers according to their spending, and rewards customers with instant price discounts and benefits (Woolworths 2014), whilst the Edgars Thank U Rewards card allows the customers to earn and accumulate points based on the monetary value of their purchases, which, in turn, can be redeemed for cash discounts (Thank U Rewards 2014). Foschini attempts to foster relationships with their customers by providing instant, unique rewards based on the customers' specific needs (The Foschini Group 2014), whilst PEP customers earn luckies (competition entries into a lucky draw for a variety of prizes) every time their PEP club card is swiped in-store (PEP Stores 2014).

Whilst clothing retailers use loyalty programmes to enhance customer relationships, Bridson, Evans and Hickman (2008:364) caution that some customers may view loyalty programmes as mere promotional tools and may switch from one clothing retailer to the next to take advantage of the best offers. For this reason, the customers' loyalty programme membership may not necessarily indicate that they are willing to respond to the clothing retailers' relationship efforts.

\section{Duration of support for a clothing retailer}

For the purpose of this study, the duration of customers' support refers to the time period during which customers have repeatedly purchased from the same clothing retailer (Rust \& Williams 1994:108). The length of time during which customers have supported a particular retailer is viewed as significant, as it is believed that longer periods of support are directly associated with retailers' profitability (Ward \& Dagger 2007:283). Further, scholars argue that the impact of relationship marketing tactics on relationship investment improves over time, suggesting that customer relationships strengthen the longer their support lasts (DeWulf et al. 2001:47; Ward \& Dagger 2007:282). Clothing retailers may assume that the length of time during which customers have supported them is indicative of their successful relationship marketing strategies. However, postulating that relationships with customers automatically strengthen over time erroneously distorts the dynamics of relationship marketing (Ward \& Dagger 2007:287). Likewise, the assumption that the duration of their support indicates customers' relationship intentions is incorrect (Parish \& Holloway 2010:69). Customers may, therefore, buy from an organisation over an extended period of time, yet lack the emotional attachment or intention to develop a relationship with that organisation (Kumar et al. 2003:670)

\section{Problem statement, research objectives and hypotheses}

Increased competition has caused clothing retailers to focus on customer retention by making substantial investments in relationship marketing tactics (Durham 2011:34; International Trade Centre 2010:15). However, the success of relationship marketing tactics depends on customers' motivation to reciprocate such efforts (De Wulf et al. 2001:33; Raciti et al. 2013:616). Clothing retailers often rely on loyalty programme membership and the duration of their customers' support to identify those with whom they want to build relationships (Bridson et al. 2008:364; Kumar et al. 2003:670). Clothing retailers could possibly benefit more by 
identifying customers with relationship intentions to ensure that valuable resources are not wasted on efforts to establish relationships with customers who do not want to respond to these efforts (Kumar et al. 2003:673; Parish \& Holloway 2010:69).

Although Kumar et al. (2003:675) propose that the relationship intention construct should be evaluated empirically across different industries, including the retail industry, relationship intention studies have been limited to service settings (Kruger \& Mostert 2012). The purpose of this study is, therefore, to determine the viability of the relationship intention concept within a clothing retail context by measuring, and then categorising, clothing retail customers according to their relationship intentions. The study furthermore explores the relationship between clothing retailer customers' relationship intentions and the length of time they have supported a clothing retailer as well as their membership to the clothing retailer's loyalty programme. The objectives of the study are:

- To determine the validity and reliability of the relationship intention measurement scale in the clothing retail context.

- To categorise clothing retail customers according to their relationship intention levels.

- To determine whether clothing retail customers with different relationship intention levels differ from one another in terms of their relationship intentions.

- To determine the relationship between loyalty programme membership and clothing retail customers' relationship intentions.

- To determine the relationship between the duration of customers' support for their clothing retailers and their relationship intentions.

The following alternative hypotheses were formulated for the study:

- $\mathbf{H}_{1}$ : Clothing retail customers with different levels of relationship intention vary significantly in terms of these intentions.

- $\mathbf{H}_{2}$ : There are significant differences between clothing retail customers' relationship intentions and their loyalty programme membership.

- $\mathbf{H}_{3}$ : There are significant associations between clothing retail customers with different relationship intention levels and their loyalty programme membership.

- $\mathbf{H}_{4}$ : There are significant differences between clothing retail customers' relationship intentions and the duration of their support.

- $\mathbf{H}_{5}$ : There are significant associations between clothing retail customers with different relationship intention levels and the duration of their support.

\section{Methodology \\ Target population and sampling}

The target population for this study was clothing retail customers aged 18 years and older, residing in the greater Pretoria metropolitan area. In the absence of a sample frame, non-probability convenience sampling was used to collect data from the respondents in the target population (Iacobucci \& Churchill 2010:287). This approach is similar to some recent South African studies (Beneke et al. 2012; Roberts-Lombard \& Immelman 2015) as well as other South African studies on relationship intention (Kruger \& Mostert 2013:339, 2015:57).

\section{Questionnaire and data collection}

An interviewer-administered survey approach using a structured questionnaire complemented the descriptive research design used for the study (Zikmund \& Babin 2013:49, 164). Trained fieldworkers approached respondents on the basis of convenience. Participation in the study was voluntary. The respondents were not asked to divulge any personal or identifiable information, thereby ensuring their anonymity.

The questionnaire commenced with a set of screening questions which would identify the respondents as part of the target population. As previous studies examining relationship marketing in the retail context emphasise that the respondents should have had regular contact with a retailer (Bettencourt 1997:393; De Wulf \& OdekerkenSchröder 2003:101), a screening question was included to ensure that they had purchased items from a clothing retailer within the past three months. A second screening question ensured that those participating in the study were the main decision makers in terms of choosing a clothing retailer from which to purchase clothing.

The first section of the questionnaire focused on determining the respondents' clothing retail patronage habits, including their loyalty programme membership and how long they had supported the clothing retailer where they shopped most frequently. Similarly to the approach followed by De Wulf and Odekerken-Schröder (2003:101), the next section focused on measuring the respondents' relationship intentions towards the clothing retailer where they shopped most often.

Previous studies have measured relationship intentions using 26 items (Kruger \& Mostert 2012:45, 2013:350). This has resulted in fielding administration issues concerning the length of the questionnaire and the time needed to complete it (Fricker et al. 2012:3). The relationship intention measurement scale proposed by Kruger and Mostert (2012:45) was therefore adapted and shortened to 15 items for the present study. Specifically, a 5-point unlabelled Likert scale, where $1=$ strongly disagree and $5=$ strongly agree, was used to measure relationship intention.

The questionnaire was pre-tested amongst 60 respondents from the target population. After minor wording changes, the data was collected by trained fieldworkers, who approached prospective respondents on the basis of convenience. In total, 511 usable questionnaires were collected from the respondents for analysis. 


\section{Data analyses}

The Statistical Package for Social Sciences (SPSS) (Version 22) was used to capture, clean and analyse the data. With reference to the normality of distribution relating to each scaled item included in the questionnaire, Curran, West and Finch (1996:16) indicate that the distribution of results can be deemed normal if it displays skewness and kurtosis absolute values of less than 2.00 and 7.00 respectively. As all the scaled items in the questionnaire were within these parameters (ranging between -0.027 to -1.425 for Skewness and 0.061 to 1.925 for Kurtosis) (Curran et al. 1996:16), as well as the fact that the sample size was relatively large, parametric tests were considered suitable for testing the hypotheses.

An exploratory factor analysis was performed to reduce the dimensionality of the data (i.e. the items used to measure relationship intentions) into a smaller set of more manageable factors (Field 2013:628; Pallant 2013:188). The exploratory factor analysis also helped the researchers understand the underlying structure of the latent variable (i.e. factors that might underlie relationship intentions) and test the validity of the shortened relationship intention measurement scale (Field 2013:628). Cronbach's alpha coefficients were calculated to assess the reliability of the scale measuring the respondents' relationship intentions (Pallant 2013:6). Field (2013:679) recommends that Cronbach's alpha coefficients should ideally be greater than 0.7 to indicate the acceptable internal consistency and reliability of the measurement scale.

In order to test the hypotheses formulated in this study, the researchers relied on a 95\% confidence level, meaning that $p$-values of less than 0.05 were interpreted as being statistically significant (Hair et al. 2013:281). An independent sample $t$-test and one-way Anovas were carried out in order to determine whether there were statistically significant differences between the means of different groups, whereas significant associations between constructs were determined by means of Pearson's chi-square tests for independence by cross-tabulating the variables (Field 2013:722; Pallant 2013:247, 258).

Although statistical significance demonstrates whether statistical differences or associations exist between variables, it does not indicate the strength of the significance (Field 2013:79). Ellis (2010:4) therefore suggests that effect sizes should be calculated to enable the researcher to judge the practical importance of an effect or a result. In this study, Cohen's $d$-values (effect size for differences) and $w$-value (effect size for associations) were calculated (Bagozzi 1994:248; Cohen 1988:25-26). Cohen (1988:25-26) explains that $d$-values can be considered small at 0.2 , medium at 0.5 , and large (practically significant) at a value greater than or equal to 0.8 . All the $d$-values were rounded off to one decimal point. In terms of the effect sizes for associations, Steyn (1999:8) suggests that $w$-values should be interpreted according to the following guidelines: $w=0.1$ indicates a small effect, $w=0.3$ indicates a medium effect and $w=$ 0.5 indicates a large effect, and a practically significant, association between variables. Similar to previous studies (Farrington 2014; Kruger \& Mostert 2013:349), this study used effect sizes that were large and practically significant (specifically $w$-values $\geq 0.5$ and $d$-values $\geq 0.8$ ) when deciding whether or not to support hypotheses.

\section{Results}

\section{Sample profile and clothing retail patronage}

Table 1 provides an overview of the sample profile and clothing retail patronage habits of the respondents who participated in the study.

From Table 1 it can be derived that, in terms of gender, more females $(61.8 \%)$ than males $(38.2 \%)$ participated in the study. Furthermore, most of the respondents were white people $(50.9 \%)$ and black people $(32.0 \%)$, the remainder being either Indian/Asian $(10.6 \%)$ or those of mixed race $(6.1 \%)$. The

TABLE 1: Sample profile and clothing retail patronage habits.

\begin{tabular}{|c|c|c|c|}
\hline Variable & Response categories & $n$ & $\%$ \\
\hline \multirow[t]{2}{*}{ Gender } & Female & 316 & 61.8 \\
\hline & Male & 195 & 38.2 \\
\hline \multirow[t]{4}{*}{ Population group } & Black & 164 & 32.0 \\
\hline & Indian/ Asian & 54 & 10.6 \\
\hline & Mixed race & 31 & 6.1 \\
\hline & White & 262 & 51.3 \\
\hline \multirow[t]{4}{*}{ Marital status } & Single & 336 & 65.8 \\
\hline & Married or living with a partner & 156 & 30.5 \\
\hline & Divorced or separated & 13 & 2.5 \\
\hline & Widow or widower & 6 & 1.2 \\
\hline \multirow[t]{5}{*}{ Highest level of education } & High school not completed & 16 & 3.1 \\
\hline & Matric / Grade 12 completed & 288 & 56.4 \\
\hline & Diploma completed & 79 & 15.4 \\
\hline & Degree completed & 94 & 18.4 \\
\hline & Post graduate degree completed & 34 & 6.7 \\
\hline \multirow{17}{*}{$\begin{array}{l}\text { Clothing retailer shopped } \\
\text { at most frequently }\end{array}$} & Ackermans & 3 & 0.6 \\
\hline & Cotton On & 16 & 3.1 \\
\hline & Donna Claire & 5 & 0.9 \\
\hline & Edgars & 116 & 22.7 \\
\hline & Factorie & 11 & 2.1 \\
\hline & Foschini & 9 & 1.8 \\
\hline & Identity & 3 & 0.6 \\
\hline & Jet & 10 & 2.0 \\
\hline & Legit & 8 & 1.6 \\
\hline & Markhams & 30 & 5.9 \\
\hline & Mr Price & 139 & 27.2 \\
\hline & Pep Stores & 7 & 1.4 \\
\hline & Queenspark & 6 & 1.2 \\
\hline & Sportscene & 5 & 0.9 \\
\hline & Truworths & 29 & 5.7 \\
\hline & Woolworths & 77 & 15.1 \\
\hline & Other & 37 & 7.2 \\
\hline \multirow{4}{*}{$\begin{array}{l}\text { Duration of supporting } \\
\text { clothing retailer shopped } \\
\text { at most frequently }\end{array}$} & Less than 1 year & 8 & 1.6 \\
\hline & $\begin{array}{l}1 \text { year or more, but less than } \\
5 \text { years }\end{array}$ & 166 & 32.5 \\
\hline & $\begin{array}{l}5 \text { years or more, but less than } \\
10 \text { years }\end{array}$ & 155 & 30.3 \\
\hline & 10 years and longer & 182 & 35.6 \\
\hline \multirow{3}{*}{$\begin{array}{l}\text { Loyalty card for clothing } \\
\text { retailer shopped at most } \\
\text { frequently }\end{array}$} & Yes & 167 & 32.7 \\
\hline & No & 291 & 56.9 \\
\hline & $\begin{array}{l}\text { Loyalty programme not offered by } \\
\text { clothing retailer }\end{array}$ & 53 & 10.4 \\
\hline
\end{tabular}


majority of the respondents were single $(65.8 \%)$, married or living with a partner $(30.5 \%)$. Regarding the highest level of education, the majority of the respondents had completed matric/grade $12(56.4 \%)$, a degree $(18.4 \%)$ or a diploma $(15.4 \%)$.

Most of the respondents shopped most frequently at $\mathrm{Mr}$ Price $(27.2 \%)$, followed by Edgars $(22.7 \%)$, Woolworths (15.1\%) and Markhams (5.9\%). Slightly more than seven per cent of the respondents indicated that they most frequently purchased clothing from 'other' clothing retailers, including lesser known clothing retailers like Jay Jays, PQ Clothing and Top Shop. How long the respondents had patronised the clothing retailer they shopped at most frequently ranged from a period of 1 year or more, but less than 5 years $(42.7 \%), 10$ years and longer $(29.2 \%)$ or 5 years or more, but less than 10 years $(23.1 \%)$. Finally, whilst the majority of the respondents $(48.5 \%)$ indicated that they did not have a loyalty card from the clothing retailer in question, $32.7 \%$ did have one, whereas $10.4 \%$ indicated that the clothing store where they bought most often did not offer a loyalty card.

\section{Exploratory factor analysis}

An exploratory factor analysis was conducted using maximum likelihood extraction with varimax rotation (Field 2013:642, 644; Hair et al. 2014:94) to identify the underlying factors constituting the clothing retail respondents' relationship intentions. The data was considered appropriate for factor analysis, as the Bartlett's test of sphericity yielded a significant result $(p<0.0001)$ and the Kaiser-Meyer-Olkin (KMO) measure of sampling adequacy (MSA) for the overall measure was 0.791 (which is greater than the recommended cut-off value 0.5) (Field 2013:647; Pallant 2013:199). Table 2 shows the rotated pattern matrix for the 15 items used to measure the respondents' relationship intentions in the clothing retail context.
In Table 2, it can be seen that five factors were extracted to measure the clothing retail respondents' relationship intentions. The five factors explain $75.40 \%$ of the total variance in the data. Furthermore, all the 15 items included in the measuring instrument loaded onto the five factors, and no items cross-loaded onto other factors. Table 2 also shows that all the items yielded factor loadings $\geq 0.5$, indicating that each item should be retained (Hair et al. 2014:116). The decision to retain all the items in the analysis was further supported by considering the MSAs for all the pairs of items reflected in the factor analysis. According to Field (2013:687), the MSA for all the pairs of items included in the factor analysis should be greater than 0.5 , and where MSA values smaller than 0.5 are found, the pair of corresponding items should be deleted from the analysis. The MSAs realised for all the pairs of items reflected in the factor analysis ranged between 0.656 and 0.849 , thereby supporting the decision not to delete any pair items from the analysis.

In Table 2, it can be seen that three items loaded onto Factor 1 relating to the respondents' concern about losing services, special privileges, or their relationship with their clothing retailer. Factor 1 was subsequently labelled Fear of relationship loss, which coincides with the label of the subconstruct that Kumar et al. (2003:667) suggested. The three items that loaded onto Factor 2 focused on the respondents' willingness to forgive their clothing retailer for bad service or for their expectations not being met. Factor 2 was consequently labelled Forgiveness, and therefore supported the 'forgiveness' sub construct proposed by Kumar et al. (2003:667). Three items loaded onto Factor 3, which focused on customers' feedback on their clothing retailers' service delivery. The items comprising Factor 3 led to its being labelled Feedback, thereby supporting the 'feedback' subconstruct proposed by Kumar et al. (2003:667). Three items loaded onto Factor 4 related to the customers' concern for the clothing retailers' image. It suggested their pride in being a customer of the clothing retailer and seeing the clothing

TABLE 2: Rotated pattern matrix for relationship intention in a clothing retail context.

\begin{tabular}{|c|c|c|c|c|c|}
\hline Items and variables & Factor 1 & Factor2 & Factor 3 & Factor 4 & Factor 5 \\
\hline I am concerned about losing special privileges from my CR by switching to another CR. & 0.851 & - & - & - & - \\
\hline I am concerned about losing the services of my CR by switching to another CR. & 0.901 & - & - & - & - \\
\hline I am concerned about losing my relationship with my CR by switching to another CR. & 0.817 & - & - & - & - \\
\hline I would forgive my CR if the quality of their service was sometimes below the standard I expect of them. & - & 0.734 & - & - & - \\
\hline I would forgive my CR if the quality of their service was below the standard of other CRs. & - & 0.859 & - & - & - \\
\hline I would forgive my CR if I experienced bad service from them. & - & 0.802 & - & - & - \\
\hline I would tell my CR if their service was better than expected. & - & - & 0.733 & - & - \\
\hline I would tell my CR if their service met my expectations. & - & - & 0.855 & - & - \\
\hline I would take the time to tell my CR about their service so that they could improve it. & - & - & 0.686 & - & - \\
\hline I am proud to be a customer of my CR. & - & - & - & 0.633 & - \\
\hline I care about the image of my CR. & - & - & - & 0.828 & - \\
\hline I feel proud when I see my CR's name or advertising materials. & - & - & - & 0.654 & - \\
\hline I expect my CR to offer me value for my money. & - & - & - & - & 0.687 \\
\hline I expect my CR to offer me more value for my money than other CRs do. & - & - & - & - & 0.819 \\
\hline Eigenvalue & 4.362 & 2.664 & 1.631 & 1.404 & 1.249 \\
\hline Cronbach alpha & 0.93 & 0.85 & 0.84 & 0.79 & 0.70 \\
\hline Percentage of variance explained & 29.082 & 17.757 & 10.871 & 9.358 & 8.324 \\
\hline
\end{tabular}


retailer's name or advertising material. The items comprising Factor 4 led to its label Involvement, which coincided with the involvement sub-construct proposed by Kumar et al. (2003:670). Lastly, the three items loaded onto Factor 5, dealing with the respondents' expectations of receiving value for money and acceptable service. Factor 5 was consequently labelled Expectations, echoing the 'expectations' sub-construct proposed by Kumar et al. (2003:667).

Table 2 also reflects the Cronbach's alpha coefficients calculated to determine the reliability of the scales used to measure the factors identified in the exploratory factor analysis. Cronbach's alpha coefficient values were greater than 0.70 , suggesting that the factors comprising relationship intention in the clothing retail setting are reliable (Hair et al. 2014:166).

According to the results of the exploratory factor analysis and Cronbach's alpha coefficients values, it can be concluded that the 15-item relationship intention measurement scale was valid and reliable when it came to measuring the respondents' relationship intentions towards their clothing retailers.

\section{Classifying respondents according to their relationship intentions}

An overall mean score was calculated for each respondent's relationship intentions (Kumar et al. 2003:675) in order to categorise the respondents into three relationship intention groups (by using the 33.3 and 66.6 percentiles as cut-points) according to their relationship intention levels. One-way Anovas was accordingly performed to determine whether there were any significant differences between the mean scores for the three relationship intention groups. Table 3 shows the descriptive statistics, Tukey's comparison (statistically significant at the 0.05 level) and $d$-values (effect sizes) for the respondents' overall relationship intentions.

Using the cut-points described, Table 3 shows that 154 respondents were classified as having low relationship intentions (mean $=2.56$ ), 202 had moderate relationship intentions (mean $=3.19$ ), and 155 respondents had high relationship intentions $($ mean $=3.86)$. Suwal $(2013)$ explains that the presence of multiple identical values at a cut-off point means that they all formed part of the same group. Consequently, the number of respondents per relationship intention group differed. Table 3 shows further that there are statistically significant differences between the three relationship intention groups, which can be regarded as practically significant, as all the effect sizes were greater than 0.8. It can therefore be concluded that hypothesis 1, stating that clothing retail customers with different levels of relationship intention differ significantly in terms of their relationship intentions, is supported.

\section{Relationship intention and loyalty programme membership}

An independent sample $t$-test was performed to determine whether significant differences existed between clothing retail customers' relationship intentions and whether they belonged to a loyalty programme offered by the clothing retailer where they shopped most often. It should be noted that respondents who indicated that their clothing retailer of choice did not offer a loyalty programme $(n=53)$ were excluded from further analysis of loyalty programme membership. Table 4 shows the descriptive statistics, the $p$-value yielded by the $t$-test and $d$-values (effect sizes) when comparing the respondents' overall relationship intention means according to their loyalty programme membership.

Table 4 demonstrates that there was a statistically significant difference between the respondents' overall relationship intentions and their loyalty programme membership $(p=0.039)$. However, a small effect size $(d=0.4)$ indicates that the difference is not practically significant. It can therefore be concluded that hypothesis 2 is not supported, because there were no significant differences between the respondents' relationship intentions and their loyalty programme membership.

It was decided to determine whether there were any significant associations between respondents with different levels of relationship intentions, and whether or not they belonged to a loyalty programme. Table 5 shows the results from a cross-tabulation between the different relationship

TABLE 3: Effect sizes for overall relationship intention for different relationship intention groups.

\begin{tabular}{|c|c|c|c|c|c|c|c|c|}
\hline \multirow[t]{2}{*}{ Construct } & \multirow[t]{2}{*}{$\mathbf{M}$} & \multirow[t]{2}{*}{ SD } & \multirow[t]{2}{*}{$n$} & \multirow[t]{2}{*}{$p$-value* } & \multirow[t]{2}{*}{ Relationship intention group } & \multicolumn{3}{|c|}{$d$-values } \\
\hline & & & & & & Low & Moderate & High \\
\hline \multirow[t]{3}{*}{ Overall relationship intention } & 2.56 & 0.238 & 154 & $1-2$ & Low & - & 2.7 & 4.3 \\
\hline & 3.19 & 0.177 & 202 & $1-3$ & Moderate & 2.7 & - & 2.2 \\
\hline & 3.86 & 0.299 & 155 & $2-3$ & High & 4.3 & 2.2 & - \\
\hline
\end{tabular}

M, Mean; SD, Standard deviation.

$1=$ low relationship intention; 2 = moderate relationship intention; 3 = high relationship intention.

*, Tukey's comparison significant at the 0.05 level

TABLE 4: Overall relationship intention and loyalty programme membership.

\begin{tabular}{|c|c|c|c|c|c|c|c|}
\hline \multirow[t]{2}{*}{ Construct } & \multirow[t]{2}{*}{$M$} & \multirow[t]{2}{*}{ SD } & \multirow[t]{2}{*}{$n$} & \multirow[t]{2}{*}{$p$-value* } & \multirow[t]{2}{*}{ Loyalty programme membership } & \multicolumn{2}{|c|}{$d$-value } \\
\hline & & & & & & Yes & No \\
\hline \multirow[t]{2}{*}{ Overall relationship intention } & 3.34 & 0.579 & 167 & 0.039 & Yes & - & 0.4 \\
\hline & 3.13 & 0.514 & 291 & - & No & 0.4 & - \\
\hline
\end{tabular}

$\mathrm{M}$, Mean; SD, Standard deviation

$*, p<0.05$ 
TABLE 5: Cross-tabulation between relationship intention groups and loyalty programme membership.

\begin{tabular}{lccc}
\hline Relationship intention group & \multicolumn{2}{c}{$\begin{array}{c}\text { Loyalty programme } \\
\text { membership }\end{array}$} & Total \\
\cline { 2 - 3 } & Yes & No & \\
\hline Low relationship intention & 41 & 95 & 136 \\
Moderate relationship intention & $30.1 \%$ & $69.9 \%$ & $100.0 \%$ \\
High relationship intention & 56 & 127 & 183 \\
& $30.6 \%$ & $69.4 \%$ & $100.0 \%$ \\
\hline Total & 70 & 69 & 139 \\
& $50.4 \%$ & $49.6 \%$ & $100.0 \%$ \\
\hline
\end{tabular}

intention groups and whether they belonged to a loyalty programme offered by their clothing retailer.

The cross-tabulation set out in Table 5 allows for the observation that most respondents with low and moderate relationship intentions did not belong to the loyalty programme offered by their clothing retailer of choice, whereas the majority of the respondents with higher relationship intention levels had loyalty programme membership. In order to determine whether there was a statistically significant association between the respondents' level of relationship intention and their loyalty programme membership, a chi-square test was performed. The test realised a $p$-value of 0.00 , indicating that there were statistically significant associations between variables. However, the realised effect size $(w=0.19)$ suggests that there was no practically significant association between the respondents' relationship intention levels and whether they belonged to the loyalty programme offered by their clothing retailer. Hypothesis 3 , stating that there are significant associations between clothing retail customers with different relationship intention levels and their loyalty programme membership, is therefore not supported.

\section{Relationship intention and the duration of support for the clothing retailer shopped at most frequently}

One-way Anovas was conducted to determine whether significant differences existed between clothing retail customers' relationship intentions and the duration of their support for their clothing retailer. As only eight respondents indicated that they had supported their clothing retailer for less than one year, the category was collapsed, together with the category one year or more, but less than five years and labelled 'less than 5 years'. Table 6 shows the descriptive statistics, the comparison with Tukey (statistically significant at the 0.05 level) and the $d$-values (effect sizes) for the respondents' overall relationship intentions.

Table 6 shows that there were no statistically or practically significant differences between the respondents' overall relationship intentions and how long they had been supporting their clothing retailer of choice. It can therefore be concluded that hypothesis 4 is not supported, as there were no significant differences between the respondents' relationship intentions and the duration of their support.
TABLE 6: Effect sizes on overall relationship intention and duration of support.

\begin{tabular}{lccccccccc}
\hline Construct & $\boldsymbol{M}$ & SD & $\boldsymbol{n}$ & $\boldsymbol{p}$-value* & $\begin{array}{c}\text { Length of } \\
\text { support }\end{array}$ & & \multicolumn{3}{c}{$\boldsymbol{d}$-value } \\
\cline { 8 - 10 } & & & & & & & & $\mathbf{2} 5<\mathbf{5 0}$ & $\mathbf{2} \mathbf{1 0}$ \\
\hline Overall & 3.27 & 0.587 & 174 & - & $<5$ & - & 0.1 & 0.2 \\
relationship & 3.20 & 0.482 & 155 & - & $\geq 5<10$ & 0.1 & - & 0.1 \\
intention & 3.15 & 0.589 & 182 & - & $\geq 10$ & 0.2 & 0.1 & - \\
\hline
\end{tabular}

M, Mean; SD Standard deviation.

*, Tukey's comparison significant at the 0.05 level

TABLE 7: Cross-tabulation between relationship intention groups and duration of support.

\begin{tabular}{lcccc}
\hline $\begin{array}{l}\text { Relationship } \\
\text { intention group }\end{array}$ & \multicolumn{3}{c}{ Duration of support } & Total \\
\cline { 2 - 4 } & $<\mathbf{5}$ years & $\begin{array}{c}\mathbf{2} \text { 5 years } \\
<\mathbf{1 0} \text { years }\end{array}$ & $\mathbf{1 0}$ years & \\
\hline Low relationship & 46 & 69 & 59 & 174 \\
intention & $26.4 \%$ & $39.7 \%$ & $33.9 \%$ & $100.0 \%$ \\
$\begin{array}{l}\text { Moderate } \\
\text { relationship }\end{array}$ & 44 & 71 & 40 & 155 \\
intention & $28.4 \%$ & $45.8 \%$ & $25.8 \%$ & $100.0 \%$ \\
$\begin{array}{l}\text { High relationship } \\
\text { intention }\end{array}$ & 64 & 62 & 56 & 182 \\
\hline Total & $35.2 \%$ & $34.1 \%$ & $30.8 \%$ & $100.0 \%$ \\
\hline & $\mathbf{1 5 4}$ & $\mathbf{2 0 2}$ & $\mathbf{1 5 5}$ & $\mathbf{5 1 1}$ \\
& $\mathbf{3 0 . 1 \%}$ & $\mathbf{3 9 . 5 \%}$ & $\mathbf{3 0 . 3 \%}$ & $\mathbf{1 0 0 . 0 \%}$ \\
\hline
\end{tabular}

Although there were no significant differences between the respondents' overall relationship intentions and how long they had supported their clothing retailer, it was decided to determine whether there were any associations between the respondents with different levels of relationship intentions and the duration of their support for their clothing retailer. Table 7 shows the results of a cross-tabulation between the different relationship intention groups and the duration of their support for the clothing retailer.

Table 7 shows that most of the respondents with low and moderate relationship intentions had been supporting their clothing retailer for 5 years or more, but for fewer than 10 years, whereas the majority of the respondents with high relationship intentions had been supporting their clothing retailer for fewer than 5 years. In order to determine whether there was a statistically significant association between the respondents' level of relationship intention and how long they had been supporting their clothing retailer, a chi-square test was performed. The test realised a $p$-value of 0.126 , indicating that no statistically significant association existed between the variables. The realised effect size $(w=0.119)$ also suggests that there was no practically significant association between variables. Hypothesis 5, stating that there were significant associations between clothing retail customers with different relationship intention levels and the duration of support is therefore not supported.

\section{Conclusion and recommendations}

Increased competition has caused clothing retailers to focus on customer retention by developing long-term customer relationships (MarketLine 2014:13; Mende, Bolton \& Bitner 2013:125). Clothing retailers often rely on loyalty programme membership and the length of time customers have supported them to determine their customers' relationship intentions (Bolton et al. 2000:95; Reinartz \& Kumar 2003:78). However, 
customers may still lack relationship intentions, so they are indifferent to the clothing retailers' relationship-building efforts, and valuable resources go to waste (Kumar et al. 2003:670). Clothing retailers would benefit by categorising their customers according to their relationship intentions and targeting those customers with higher relationship intentions when it comes to relationship marketing efforts.

This study sought to determine the feasibility of considering relationship intention in the context of clothing retail. The study also explored the duration of the customers' support for a particular clothing retailer, their membership of the clothing retailer's loyalty programme and the relationship of these with their relationship intentions. The results of an exploratory factor analysis indicate that the relationship intention measurement scale adapted for this study was valid and reliable in measuring customers' relationship intentions towards clothing retailers in the greater Pretoria metropolitan area. This study, therefore, provides clothing retailers with a valid and reliable relationship intention measurement scale that can be used to determine their customers' relationship intentions. The results from this study show that the respondents could be divided into three different relationship intention groups that significantly differ practically from one another. It can, therefore, be recommended that clothing retailers categorise their customers according to their relationship intentions, and focus their relationship-building efforts more on customers with higher relationship intentions.

The findings also indicate that no relationship exists between the customers' membership of the clothing retailer's loyalty programme and their relationship intentions, as customers' overall relationship intentions did not differ according to whether they belonged to a loyalty programme offered by the clothing retailer where they shopped most often. Similarly, no significant associations could be found between clothing retail customers with different levels of relationship intentions and membership of a loyalty programme offered by the clothing retailer. These findings support the notion that some customers view loyalty programmes simply as promotional tools (Bridson et al. 2008:364). It is, therefore, recommended that clothing retailers practise caution when relying on loyalty programme membership to identify customers for relationship-building efforts. Instead, clothing retailers should identify customers with higher levels of relationship intentions and target those customers with their relationship marketing tactics.

The results also show that there were no significant differences between the respondents' relationship intentions and how long they had supported their preferred clothing retailer. Similarly, there were no significant associations between clothing retail customers with different relationship intention levels and how long they had supported their clothing retailer. It can, therefore, be concluded that no relationship exists between the duration of customers' support for their clothing retailer and their relationship intentions. These findings support the view of Kumar et al.
(2003:670) that customers' relationship intentions do not automatically develop over time, as customers can support an organisation over an extended period and still be without relationship intention. Subsequently, clothing retailers should not assume that customers who have supported them over a period of time have intentions of building longterm relationships. Instead, it is recommended that clothing retailers identify customers with relationship intentions, as profitability from such customers will increase over time (Kumar et al. 2003:673).

\section{Limitations and future research}

The limitations of the study include the use of non-probability convenience sampling, which suggests that the findings can be generalised only to the respondents who participated in this study. Furthermore, the results are limited to one retail setting, namely clothing, which is characterised by low switching barriers (Bettencourt 1997; MarketLine 2014:13). Also, owing to cost constraints, the study was confined to one metropolitan area, implying that different results for relationship intention may have been obtained if more metropolitan areas had been included. Lastly, this study did not explore possible antecedents of relationship intentions, which could have provided better insight into the development of the customers' relationship intentions.

Future research studies could consider collaboration with a national clothing retailer to determine their customers' relationship intentions. Extending the study across different retailer types (characterised by different product categories and retail mix strategies) could also offer insights into the applicability of customers' relationship intentions in different retail settings. Lastly, future studies should examine the antecedents of relationship intention, including the retailer, the channel and brand equity (Kumar et al. 2003:671-672), and individual customer characteristics, including gender, age, ethnicity and the attitude to retail relationships.

\section{Acknowledgements Competing interests}

The authors declare that they have no financial or personal relationship(s) that may have inappropriately influenced them in writing this article.

\section{Authors' contributions}

S.W.K. is a PhD student at the North-West University (NWU). This is the first article from her thesis. P.G.M. (University of Pretoria) is the supervisor for the study.

\section{References}

Adjei, M.T. \& Clark, M.N., 2010, 'Relationship marketing in A B2C context: The moderating role of personality traits', Journal of Retailing and Consumer Services 17, 73-79. http://dx.doi.org/10.1016/j.jretconser.2009.10.001

Adjei, M.T., Griffith, D.A. \& Noble, S.M., 2009, 'When do relationships pay off for smal retailers? Exploring targets and contexts to understand the value of relationship marketing', Journal of Retailing 85(4), 493-501. http://dx.doi.org/10.1016/j. jretai.2009.09.001 
Agariya, A.K. \& Singh, D., 2011, 'What really defines relationship marketing? A review of definitions and general and sector-specific defining constructs', Journal of Relationship Marketing 10(4), 203-237. http://dx.doi.org/10.1080/15332667.20 Relationship
11.624905

Ashley, C., Noble, S.M., Donthu, N. \& Lemon, K.N., 2011, 'Why customers won't relate: Obstacles to relationship marketing engagement', Journal of Business Research 64, 749-756. http://dx.doi.org/10.1016/j.jbusres.2010.07.006

Bagozzi, R.P., 1994, 'Structural equation models in marketing research: Basic principles', in R.P. Bagozzi (ed.), Principles of marketing research, pp. 317-385, Blackwell Business, Cambridge.

Baker, T.L., Cronin, J.C. \& Hopkins, C.D., 2009, 'The impact of involvement on key service relationships', Journal of Services Marketing 23(2), 115-124. http://dx.doi. org/10.1108/08876040910946378

Beneke, J., Hayworth, C., Hobson, R. \& Mia, Z., 2012, 'Examining the effect of retail service quality dimensions on customer satisfaction and loyalty', Acta Commerci 12(1), 27-43.

Bettencourt, L.A., 1997, 'Customer voluntary performance: Customers as partners in service delivery', Journal of Retailing 73(3), 383-406. http://dx.doi.org/10.1016/ S0022-4359(97)90024-5

Blodgett, J.G., Wakefield, K.L. \& Barnes, J.H., 1995, 'The effects of customer service on consumer complaining behavior', Journal of Services Marketing 9(4), 31-42. on consumer complaining behavior', Journal of
http://dx.doi.org/10.1108/08876049510094487

Bojei, J., Julian, C.C., Wel, C.A.B.C. \& Ahmed, Z.U., 2013, 'The empirical link between relationship marketing tools and consumer retention in retail marketing', Journa of Consumer Behaviour 12, 171-181. http://dx.doi.org/10.1002/cb.1408

Bolton, R.N., Kannan, P.K. \& Bramlett, M.D., 2000, 'Implications of loyalty program membership and service experiences for customer retention and value', Journal of the Academy of Marketing Science 28(1), 95-108. http://dx.doi. org/10.1177/0092070300281009

Bove, L. \& Mitzifiris, B., 2007, 'Personality traits and the process of store loyalty in a transactional prone context', Journal of Services Marketing 21(7), 507-519. http://dx.doi.org/10.1108/08876040710824861

Bridson, K., Evans, J. \& Hickman, M., 2008, 'Assessing the relationship between loyalty program attributes, store satisfaction and store loyalty', Journal of Retailing and Consumer Services 15, 364-374. http://dx.doi.org/10.1016/j.jretconser.2007.08.004

Caemmerer, B. \& Wilson, A., 2010, 'Customer feedback mechanisms and organisational learning in service operations', International Journal of Operations and Production Management 30(3), 288-311. http://dx.doi.org/10.1108/01443571011024638

Choy, J.Y., Lam, S.Y. \& Lee, T.C., 2012, 'Service quality, customer satisfaction and behavioral intentions: Review of literature and conceptual model development', International Journal of Academic Research 4(3), 11-15.

Christopher, M., Payne, A. \& Ballantyne, D., 2008, Relationship marketing: Creating stakeholder value, Butterworth-Heinemann, Oxford.

Cohen, J., 1988, Statistical power analysis for the behavioral sciences, 2nd edn., Lawrence Erlbaum Associates, Hillsdale.

Curran, P.J., West, S.G. \& Finch, J.F., 1996, 'The robustness of test statistics to nonnormality and specification error in confirmatory factor analysis', Psychological Methods 1(1), 16-29. http://dx.doi.org/10.1037/1082-989X.1.1.16

Dagger, T.S. \& David, M.E., 2012, 'Uncovering the real effect of switching costs on the satisfaction-loyalty association: The critical role of involvement and relationship benefits', European Journal of Marketing 46(4), 447-468. http://dx.dol. org/10.1108/03090561211202558

Dagger, T.S., David, M.E. \& Ng, S., 2011, ‘Do relationship benefits and maintenance drive commitment and loyalty?', Journal of Services Marketing 25(4), 273-281. http://dx.doi.org/10.1108/08876041111143104

Dalziel, N., Harris, F. \& Laing, A., 2011, 'A multidimensional typology of customer relationships: From faltering to affective', International Journal of Bank Marketing 29(5), 398-432. http://dx.doi.org/10.1108/02652321111152918

De Cannière, M.H., De Pelsmacker, P. \& Geuens, M., 2010, 'Relationship quality and purchase intention and behavior: The moderating impact of relationship strength', Journal of Business Psychology 25, 87-98. http://dx.doi.org/10.1007/s10869-0099127-z

De Wulf, K. \& Odekerken-Schröder, G., 2003, 'Assessing the impact of a retailer's relationship efforts on consumers' attitudes and behaviour', Journal of Retailing and Consumer Services 10, 95-108. http://dx.doi.org/10.1016/S09696989(02)00013-9

De Wulf, K., Odekerken-Schröder, G., de Canniére, H. \& Van Oppen, C., 2003, 'What drives consumer participation to loyalty programs?', Journal of Relationship Marketing 2(2), 69-83. http://dx.doi.org/10.1300/J366v02n01 05

De Wulf, K., Odekerken-Schröder, G. \& lacobucci, D., 2001, 'Investments in consumer relationships: A cross-country and cross-industry exploration', Journal of Marketing 65(4), 33-50. http://dx.doi.org/10.1509/jmkg.65.4.33.18386

Durham, L., 2011, 'Trend tracker: Opportunities and challenges for South African retailers, Supermarket and Retailer, 33-35.

Ellis, P.D., 2010, The essential guide to effect sizes: Statistical power, meta-analysis, and the interpretation of research results, Cambridge University Press, New York. http://dx.doi.org/10.1017/CBO9780511761676

Farrington, S.M., 2014, 'A comparative study of the entrepreneurial orientation of small family and small non-family businesses', Management Dynamics 23(2), 26-43.

Fernandes, T. \& Proença, J., 2013, 'Reassessing relationships in consumer markets: Emotion, cognition, and consumer relationship intention', Journal of Relationship Marketing 12(1), 41-58. http://dx.doi.org/10.1080/15332667.2013.763719

Field, A., 2013, Discovering statistics using IBM SPSS statistics, 4th edn., Pearson, London.
Fricker, S., Creech, B., Davis, J., Gonzalez, J., Tan, L. \& To, N., 2012, 'Does length really matter? Exploring the effects of a shorter interview on data quality, nonresponse, and respondent burden', paper presented at Federal Committee on statistical methodology 2012 research conference, Washington, DC, viewed 12 August 2014 from http://www.fcsm.gov/12papers/Fricker_2012FCSM_IX-B. pdf.

Grewal, D. \& Levy, M., 2007, 'Retailing research: Past, present and future', Journal of Retailing 4, 447-464. http://dx.doi.org/10.1016/j.jretai.2007.09.003

Hair, J.F., Black, W.C., Babin, B.J. \& Anderson, R.E., 2014, Multivariate data analysis, 7th edn., Pearson, Harlow.

Hair, J.F., Celsi, M.W., Oritinau, D.J. \& Bush, R.P., 2013, Essentials of marketing research, 3rd edn., McGraw-Hill Irwin, New York.

Henning-Thurau, T., Gwinner, K.P. \& Gremler, D.D., 2002, ‘Understanding relationship marketing outcomes: An integration of relational benefits and relationship quality', Journal of Services Research 4(3), 230-247. http://dx.doi. org/10.1177/1094670502004003006

Homburg, C., Giering, A. \& Menon, A., 2003, 'Relationship characteristics as moderators of the satisfaction loyalty link: Finding in a business-to-business context', Journal of Business-to-Business Marketing 10(3), 35-62. http://dx.doi. org/10.1300/J033v10n03_02

Huang, M.H., 2015, 'The influence of relationship marketing investments on customer gratitude in retailing', Journal of Business Research 68(6), 1318-1323. http:// dx.doi.org/10.1016/j.jbusres.2014.12.001

Iacobucci, D. \& Churchill, G.A., 2010, Marketing research: Methodological foundations, 10th edn., South-Western/ Cengage Learning, Melbourne.

International Trade Centre, 2010, South Africa: A market for clothing from Africa, viewed 22 April 2014, from http://www.intracen.org/uploadedFiles/intracenorg/ Content/Exporters/Sectors/Food and agri business/Cotton/AssetPDF/final\%20 clothing $\% 20$ for $\% 20$ africa $\% 2030-12-10 \% 20$ with $\% 20$ cover.pdf.

Johnson, B.R. \& Ross, W.T., 2014, 'The consequences of consumers' use of pre-existing social relationships to make purchases', Journal of Relationship Marketing 13(3) 207-242. http://dx.doi.org/10.1080/15332667.2014.939018

Jones, M.A., Reynolds, K.E., Mothersbaugh, D.L. \& Beatty, S.E., 2007, 'The positive and negative effects of switching costs on relational outcomes', Journal of Service Research 9(4), 335-355. http://dx.doi.org/10.1177/1094670507299382

Kim, W., Ok, C. \& Canter, D.D., 2012, 'Moderating role of a priori customer-firm relationship in service recovery situations', The Service Industries Journal 32(1), 59-82. http://dx.doi.org/10.1080/02642069.2010.506571

Kinard, B.R. \& Capella, M.L., 2006, 'Relationship marketing: The influence of consumer involvement on perceived service benefits', Journal of Services Marketing 20(6), 359-368. http://dx.doi.org/10.1108/08876040610691257

Kruger, L. \& Mostert, P.G., 2012, 'Young adults' relationship intentions towards their cellphone network operators', South African Journal of Business Management 43(2), 41-49.

Kruger, L. \& Mostert, P.G., 2013, 'The influence of relationship intention on relationship length and contractual agreements', Journal of Contemporary Management 10, 339-361.

Kruger, L. \& Mostert, P.G., 2015, 'The influence of cell phone users' relationship intentions on expectations and perceptions of service recovery', South African Journal of Business Management 46(1), 57-69.

Kumar, V., Bohling, R. \& Ladda, R.N., 2003, 'Antecedents and consequences of relationship intention: Implications for transactional and relationship marketing', Industrial Marketing Management 32(8), 667-676. http://dx.doi.org/10.1016/j. indmarman.2003.06.007

Lacey, R., 2012, 'How customer voice contributes to stronger service provider relationships', Journal of Services Marketing 26(2), 137-144. http://dx.doi. org/10.1108/08876041211215293

Leahy, R., 2011, 'Relationships in fast moving consumer markets', European Journal of Marketing 45(4), 651-672. http://dx.doi.org/10.1108/03090561111111370

Leenheer, J. \& Bijmolt, T.H.A., 2008, 'What retailers adopt a loyalty program? An empirical study', Journal of Retailing and Consumer Services 15, 429-442. http:// dx.doi.org/10.1016/j.jretconser.2007.11.005

Liang, C.J. \& Wang, W.H., 2006, 'The behavioural sequence of the financial services industry in Taiwan: Service quality, relationship quality and behavioural loyalty', Service Industries Journal 26(2), 119-145. http://dx.doi.org/10.1080/02642060500369131

Liang, C.J. \& Wang, W.H., 2007, 'An insight into the impact of a retailer's relationship efforts on customers' attitudes and behavioral intentions', International Journal of Bank Marketing 25(5), 336-366. http://dx.doi.org/10.1108/02652320710772998

Liu, Y., 2007, 'The long-term impact of loyalty programs on consumer purchase behaviour and loyalty', Journal of Marketing 71(4), 19-35. http://dx.doi. org/10.1509/jmkg.71.4.19

Mark, T., Lemon, K., Vandenbosch, M., Bulla, J. \& Maruotti, A., 2013, 'Capturing the evolution of customer-firm relationships: How customers become more (or less) valuable over time', Journal of Retailing 89(3), 231-245. http://dx.doi. org/10.1016/j.jretai.2013.04.001

MarketLine, 2014, 'Apparel retail in South Africa', viewed 3 November 2014, from http://eds.b.ebscohost.com.nwulib.nwu.ac.za/bsi/pdfviewer/pdfviewer? $\mathrm{vid}=3 \& \mathrm{sid}=7 \mathrm{c} 28 \mathrm{f037}-461 \mathrm{c}-4 \mathrm{ae} 9-\mathrm{b} 122-317 \mathrm{abe} 39979 \mathrm{a} \% 40$ sessionmgr110\& $\mathrm{h}$ $\mathrm{id}=114$

Mason, C. \& Simmons, J., 2012, 'Are they being served? Linking consumer expectation, evaluation and commitment', Journal of Services Marketing 26(4), 227-237. $\mathrm{http}: / / \mathrm{dx}$.doi.org/10.1108/08876041211237532

Mauri, C., 2003, 'Card loyalty: "A new emerging issue in grocery retailing"', Journa of Retailing and Consumer Services 10, 13-25. http://dx.doi.org/10.1016/S09696989(02)00036-X 
Mende, M., Bolton, R.N. \& Bitner, M.J., 2013, 'Decoding customer-firm relationships: How attachment styles help explain customers' preference for closeness, repurchase intentions, and changes in relationship breadth', Journal of Marketing Research 125-142. http://dx.doi.org/10.1509/jmr.10.0072

Meyer-Waarden, L., 2008, 'The influence of loyalty programme membership on customer purchase behaviour', European Journal of Marketing 42(2), 87-114. http://dx.doi.org/10.1108/03090560810840925

Odekerken-Schröder, G., De Wulf, K. \& Schumacher, P., 2003, 'Strengthening outcomes of retailer-consumer relationships: The dual impact of relationship marketing tactics and consumer personality', Journal of Business Research 56, 177-190. http://dx.doi.org/10.1016/S0148-2963(01)00219-3

Oliver, R.L., 1980, 'A cognitive model of the antecedents and consequences of satisfaction decisions', Journal of Marketing Research 17(4), 460-469. http:// dx.doi.org/10.2307/3150499

O'Cass, A., 2000, 'An assessment of consumers product, purchase decision, advertising and consumption involvement in fashion clothing', Journal of Economic Psychology 21, 545-576. http://dx.doi.org/10.1016/S0167-4870(00)00018-0

O'Malley, L. \& Tynan, C., 2000, 'Relationship marketing in consumer markets: rhetoric or reality?', European Journal of Marketing 34(7), 797-815. http://dx.doi. org/10.1108/03090560010331225

Pallant, J., 2013, SPSS survival manual, 5th edn., McGraw-Hill, New York.

Palmatier, R.W., Scheer, L.K., Houston, M.B., Evans, K.R. \& Gopalakrishna, S., 2007 'Use of relationship marketing programs in building customer-salesperson and customer-firm relationships: Differential influences on financial outcomes', International Journal of Research in Marketing 24, 210-223. http://dx.doi. org/10.1016/j.ijresmar.2006.12.006

Parish, J.T. \& Holloway, B.B., 2010, 'Customer relationship proneness: A reexamination across service exchanges', Journal of Services Marketing 24(1), 61-73. http:// dx.doi.org/10.1108/08876041011017899

Pep Stores, 2014, 'About PEP club', viewed 25 October 2014, from http://www. pepstores.com/pepclub/about/.

Priluck, R., 2003, 'Relationship marketing can mitigate product and service failure', Journal of Services Marketing 7(1), 37-50. http://dx.doi.org/10.1108/ 08876040310461264

Raciti, M.M., Ward, T. \& Dagger, T.S., 2013, 'The effect of relationship desire on consumerto-business relationships', European Journal of Marketing 47(4), 615-634. $\mathrm{http}: / / \mathrm{dx}$.doi.org/10.1108/03090561311297490

Reinartz, W.J. \& Kumar, V., 2003, 'The impact of customer relationship characteristics on profitable lifetime duration', Journal of Marketing 67(1), 77-90. http://dx.doi. org/10.1509/jmkg.67.1.77.18589

Roberts-Lombard, M. \& Immelman, R., 2015, 'Guidelines for the marketing of independent schools in South Africa', Acta Commercii 15(1), 1-9.

Rothenberger, S., Grewal, D. \& Iyer, G.R., 2008, 'Understanding the role of complaint handling on consumer loyalty in service relationships', Journal of Relationship Marketing 7(4), 359-376. http://dx.doi.org/10.1080/15332660802516029

Rust, R.T. \& Williams, D.C., 1994, 'How length of patronage affects the impact of customer satisfaction on repurchase intentions', Journal of Consumer Satisfaction, Dissatisfaction, and Complaining Behaviour 7, 107-113.

Sheth, J. \& Parvatiyar, A., 1995, 'Relationship marketing in consumer markets: Antecedents and consequences', Journal of the Academy of Marketing Science 23(4), 255-271. http://dx.doi.org/10.1177/009207039502300405

Singh, J. \& Sirdeshmukh, D., 2000, 'Agency and trust mechanisms in consumer satisfactions and loyalty judgments', Journal of the Academy of Marketing Science 28(1), 150-167. http://dx.doi.org/10.1177/0092070300281014
Steyn, H.S., 1999, Praktiese beduidendheid: Die gebruik van effekgroottes, Publikasiebeheerkomitee, Potchefstroomse Universiteit vir Christelike Hoër Onderwys, Potchefstroom.

Suwal, S., 2013, 'Visual binning', viewed 3 November 2014, from http://www. slideshare.net/sarosem1/visual-binning.

Thank U Rewards, 2014, 'Thank U Rewards', viewed 25 October 2014, from http:// www.redsquare.co.za/thank-u-rewards/?gclid=Cj0KEQjwIK2iBRDk0Jnjso6AgM0B EiQAdX-iY4lavYdzPeySFcp3L8VMPzXIWpN5SBSn59RCneHfahkaAosI8P8HAQ.

The Foschini Group, 2014, 'Get rewards every time you shop', viewed 25 October 2014, from http://www.tfg.co.za/rewards-and-more.

Tsarenko, Y. \& Tojib, D.R., 2011, 'A transactional model of forgiveness in the service failure context: A customer-driven approach', Journal of Services Marketing 25(5), 381-392. http://dx.doi.org/10.1108/08876041111149739

Varki, S. \& Wong, S., 2003, 'Consumer involvement in relationship marketing of services', Journal of Service Research 6(1), 89-91. http://dx.doi. org $/ 10.1177 / 1094670503254287$

Vázquez-Casielles, R., Suárez-Álvarez, L., Río-Lanza, D. \& Belén, A., 2009, 'Customer satisfaction and switching barriers: Effects on repurchase intentions, positive recommendations, and price tolerance', Journal of Applied Social
Psychology 39(10), 2275-2302. http://dx.doi.org/10.1111/j.1559-1816.2009. 00526.x

Vesel, P. \& Zabkar, V., 2010, 'Managing customer loyalty through the mediating role of satisfaction in the DIY retail loyalty program', Journal of Retailing and role of satisfaction in the DIY retail loyalty program, Journal of Retailing and
Consumer Services 16, 396-406. http://dx.doi.org/10.1016/j.jretconser.2009. 05.002

Voss, C.A., Roth, A.V., Rosenzweig, E.D., Blackmon, K. \& Chase, E.B., 2004, 'A tale of two countries' conservatism, service quality and feedback on customer satisfaction', Journal of Service Research 6(3), 212-230. http://dx.doi. org/10.1177/1094670503260120

Ward, T. \& Dagger, T.S., 2007, 'The complexity of relationship marketing for service customers', Journal of Services Marketing 21(4), 281-290. http://dx.doi. org/10.1108/08876040710758586

Wilson, A., Zeithaml, V.A., Bitner, M.J. \& Gremler, D.D., 2012, Services marketing: Integrating customer focus across the firm, McGraw-Hill, London.

Wirtz, J., Tambyah, S.K. \& Mattila, A.S., 2010, 'Organizational learning from customer feedback received by service employees: A social capital perspective', Journal of Service Management 21(3), 363-387. http://dx.doi. org/10.1108/09564231011050814

Wong, A. \& Sohal, A.S., 2006, 'Understanding the quality of relationships in consumer services: A study in a retail environment', International Journal of Quality and Reliability Management 23(3), 244-264. http://dx.doi. org $/ 10.1108 / 02656710610648215$

Woolworths, 2014, 'WRewards: How it works', viewed 12 August 2014, from: http://www.woolworths.co.za/store/fragments/wrewards/wrewards-index. jsp?content=how-it-works.

Yu, Q. \& Xie, X., 2011, 'Forgive your failures: How the customer-organization relationship benefits for the service recovery?', IEEE 2011 International Conference on Management and Service Science (MASS), Wuhan, 12-14 August, pp. 1-3. http://dx.doi.org/10.1109/icmss.2011.5998854

Zeithaml, V.A., Berry, L.L. \& Parasuraman, A., 1993, 'The nature and determinants of customer expectations of service', Journal of the Academy of Marketing Science 21(1), 1-12. http://dx.doi.org/10.1177/0092070393211001

Zikmund, W.G. \& Babin, B.J., 2013, Essentials of marketing research, 5th edn., South Western/Cengage Learning, Melbourne. 